ISSN (Print) : :1412-7601

ISSN (Online) : 2654-8712

Volume 6, No.2 September 2020

EKONOBIS

http://www.ekonobis.unram.ac.id

\title{
Pengembangan Pariwisata Di Desa Timbanuh Kecamatan Pringgasela Kabupaten Lombok Timur Dan Dampaknya Terhadap Pendapatan Masyarakat
}

\section{Baiq Ismiwati, Himawan Sutanto, Salamah}

Universitas Mataram

\section{ARTICLE INFO}

Keywords :

Tourism development, community income
ABSTRACT : This research entitled "Tourism Development in Timbanuh Village, Pringgasela District, East Lombok Regency and Its impact on Community Income". The aim of this research is to know the activities or businesses that can add value to the community by developing tourism and its impact on the income of the community around Timbanuh Village, Pringgasela District, East Lombok Regency. The type of research used is descriptive research. The data collected by using survey sample method where the data were obtained by interview, observation and documentation. The type of data used is quantitative and qualitative data. The data sourced from primary data and secondary data and analyzed by using income analysis and independent sample t-test.

The results showed that before tourism development (natural tourism object), community economic activities in general were: trading, gardening, raising livestock and farming. After developing the tourism by improving natural tourism facilities and infrastructure, the variety or types of community activities have become more varied, namely the number of traders has increased, there are porters, parking attendants and lodging services. The results of the independent sample t-test showed that there was difference in community income before and after tourism development. So, the development of tourism has a positive impact on the income of the community around Timbanuh Village, Pringgasela District, East Lombok Regency.

Kata Kunci : ABSTRAK: Penelitian ini berjudul "Pengembangan Wisata di Desa Timbanuh Kecamatan Pringgasela Kabupaten Lombok Timur dan Dampaknya terhadap Pendapatan Masyarakat". Tujuan dari penelitian ini adalah untuk mengetahui kegiatan atau usaha yang dapat memberikan nilai tambah bagi masyarakat dengan mengembangkan pariwisata dan dampaknya terhadap pendapatan masyarakat sekitar Desa Timbanuh Kecamatan Pringgasela Kabupaten Lombok Timur.

Jenis penelitian yang digunakan adalah penelitian deskriptif. Pengumpulan data dilakukan dengan menggunakan metode sampel survei dimana data diperoleh dengan wawancara, observasi dan dokumentasi. Jenis data yang digunakan adalah data kuantitatif dan kualitatif. Data bersumber dari data primer dan data sekunder dan dianalisis dengan menggunakan analisis pendapatan dan uji independent sample t-test. Hasil penelitian menunjukkan bahwa sebelum pengembangan wisata (objek wisata alam) kegiatan ekonomi masyarakat pada umumnya adalah: berdagang, berkebun, beternak dan bertani. Setelah mengembangkan pariwisata dengan meningkatkan sarana dan prasarana wisata alam, maka ragam atau jenis kegiatan masyarakat semakin bervariasi yaitu jumlah pedagang yang semakin banyak, ada kuli angkut, tukang parkir dan jasa penginapan. Hasil uji independent sample t-test menunjukkan ada perbedaan pendapatan masyarakat sebelum dan sesudah pengembangan pariwisata. Sehingga perkembangan pariwisata berdampak positif bagi pendapatan masyarakat sekitar Desa Timbanuh, Kecamatan Pringgasela, Kabupaten Lombok Timur.

Corresponding Author :

Alamat : Program Studi Ekonomi Pembangunan, Fakultas Ekonomi dan Bisnis, Universitas Mataram, Jln. Majapahit No. 62 Mataram.

e-mail: ismiwati2010@gmail.com

2020, EKONOBIS All right reserved 


\section{PENDAHULUAN}

\section{Latar Belakang}

Di era globalisasi seperti sekarang ini, pembangunan dunia pariwisata dapat dijadikan sebagai prioritas utama dalam menunjang pembangunan suatu daerah. Pengembangan pariwisata dilakukan bukan hanya untuk kepentingan wisatawan mancanegara saja, namun juga untuk menggalakan kepentingan wisatawan dalam negeri maupun masyarakat sekitar daerah wisata. Pembangunan kepariwisataan pada hakekatnya untuk mengembangkan dan memanfaatkan obyek dan daya tarik wisata yang berupa kekayaan alam yang indah, keragaman flora fauna, seni budaya, peninggalan sejarah, bendabenda purbakala serta kemajemukan budaya.

Tujuan pengembangan pariwisata akan berhasil dengan optimal bila ditunjang oleh potensi daerah yang berupa obyek wisata baik wisata alam maupun wisata buatanmanusia. Yoeti (1985: 5), mengatakan bahwa pembangunan dan pengembangan daerah menjadi daerah tujuan wisata tergantung dari daya tarik itu sendiri yang dapat berupa keindahan alam, tempat bersejarah, tata cara hidup bermasyarakat maupun upacara keagamaan. Melihat fenomena seperti uraian diatas, sektor kepariwisataan perlu mendapat penanganan yang serius karena kepariwisataan adalah merupakan kegiatan lintas sektoral dan lintas wilayah yang saling terkait, diantaranya dengan sektor industri, perdagangan, pertanian, perhubungan, kebudayaan, sosial ekonomi, politik, keamanan serta lingkungan. Keterkaitan ini selanjutnya akan berdampak pada kesejahteraan masyarakat di sekitar daerah wisata tersebut.

Menurut Kuncoro (2019), Pilar utama pariwisata adalah tiga subsektor, yaitu perdagangan besar dan eceran, hotel dan restoran. Pengklasifikasian ini dilakukan ketika sektor-sektor yang membentuk PDB/PDRB masih 9 sektor. Sementara saat ini sektor sektor yang masuk dalam pembentukan PDB ataupun PDRB ada 17 sektor, dan paling erat kaitannya dengan sektor pariwisata adalah sektor Perdagangan besar dan eceran, sektor Transportasi dan pergudangan dan Sektor Penyediaan akomodasi dan Makan. Disamping ketiga sector tersebut sector pariwisata tentunya akan berpengaruh pada sector lainnya, seperti sector jasajasa, industry maupun pada sector pertanian. Pada tahun 2017 kontribusi ketiga sektor ini cukup besar terhadap 
PDRB NTB yakni sebesar 22,70 persen dengan laju pertumbuhan tiga sector pendukung pariwisata (Perdagangan besar dan Eceran, Transportasi dan Pergudangan dan Penyediaan Akomodasi dan Makan Minum selama 2015 -2017 rata-rata sebesar 7,08 persen.

Pariwisata NTB perlu terus di dorong lebih baik agar semakin banyak wisatawan yang datang berkunjung ke NTB sehingga perekonomian di NTB pun semakin meningkat. Oleh karena itu, Pemerintah terus membangun dan mengembangkan sektor pariwisata dalam berbagai bidang, diantaranya sektor wisata alam, wisata kuliner, wisata budaya, wisata religi dan wisata lainnya.

Kabupaten Lombok Timur merupakan salah satu kabupaten di Provinsi NTB, yang juga sedang giat dalam mengembangkan sektor pariwisata. Lombok Timur memiliki banyak destinasi wisata yang tidak kalah menarik dengan daerah lain di NTB. Diantara destinasi wisata tersebut, ada wisata pantai, wisata pegunungan, wisata budaya dan lain sebagainya. Semuanya memiliki daya tarik tersendiri sehigga diharapkan dapat menambah jumlah kunjungan wisatawan ke wilayah Lombok Timur. Berdasarkan data dari BPS Lombok Timur jumlah kunjungan wisatawan di Kabupaten
Lombok Timur terus meningkat dari tahun ke tahun dengan rata-rata pertumbuhan periode tahun 2013-2016 sebesar 26,91 persen.

Kabupaten Lombok Timur memiliki beragam Objek Daerah Tujuan Wisata (ODTW) yang sangat menarik untuk dikunjungi oleh wisatawan. Diantaranya adalah desa Timbanuh yang merupakan salah satu daerah wisata yang terletak di lingkar gunung Rinjani dan masuk dalam kawasan Taman Nasional Gunung Rinjani (TNGR). Potensi wisata desa ini cukup besar untuk dikelola dan dikembangkan dan kini selalu ramai dikunjungi para wisatawan baik itu domestik maupun mancanegara. Desa Timbanuh memiliki beberapa destinasi wisata diantaranya, wisata air terjun Mayung Polak, air terjun Semporonan, bangunan bersejarah peninggalan Belanda, kolam renang bentukan Belanda, prosotan alami Air Sleong dan surganya para pendaki yaitu merupakan salah satu jalur trekking ke gunung Rinjani yang dikenal sebagai jalur selatannya gunung Rinjani.

Besarnya potensi desa Timbanuh dibidang pariwisata menyebabkan desa ini cukup mendapatkan perhatian dari pemerintah daerah Lombok Timur. Pemda Lotim sudah mulai melakukan sentuhan terhadap prasarana dan sarana yang ada 
di desa. Jalan menuju ke lokasi desa Timbanuh sudah diperbaiki, jalan-jalan baru sudah banyak di buka sehingga lebih memudahkan akses ke desa ini, termasuk juga memudahkan akses masyarakat setempat dalam melakukan berbagai kegiatan, termasuk kegiatan ekonomi.

Fasilitas penunjang juga sekarang sudah mulai dibenahi seperti disediakannya tempat sampah, toilet umum, dan street sign menuju lokasi wisata. Bahkan di jalur trekking Rinjani juga di setiap pos sudah di buatkan tempat sampah, toilet umum, tempat mengambil air, tempat solat, dan tempat istirahat. Sejak mulai dibangunnya sarana prasarana dan fasilitas wisata di Desa Timbanuh, para wisatawan mancanegara maupun lokal sudah mulai banyak yang berkunjung ke Desa Timbanuh.

Berdasarkan jumlah kunjungan wisatawan di pendakian jalur selatan Timbanuh, dari tahun ketahun jumlah pengunjung yang mendaki lewat jalur selatan semakin ramai. Berdasarkan data yang di peroleh dari tahun 2015 sampai 2017 jumlah wisatawan yang berkunjung melalui jalur selatan Timbanuh sebagai berikut :

Tabel 1. Jumlah Kunjungan Wisatawan Pendakian Jalur Selatan

(Desa Timbanuh) Tahun 2015-2017

\begin{tabular}{|c|c|c|}
\hline NO & TAHUN & JUMLAH WISATAWAN \\
\hline 1 & 2015 & 1,637 \\
\hline 2 & 2016 & 1.282 \\
\hline 3 & 2017 & 1.514 \\
\hline \multicolumn{2}{|c|}{ TOTAL KUNJUNGAN } & 4,433 \\
\hline
\end{tabular}

Sumber: Balai Taman Nasional Gunung Rinjani

Sebelum adanya pengembangan wisata di desa timbanuh rata-rata mata pencarian masyarakat hanya berkebun dan beternak. Setelah pariwisata mulai dikembangkan pola pikir masyarakat mulai berubah. Banyak pemuda dan masyarakat mulai berfikir bagaimana cara mengelola dan membangun desanya agar lebih maju dan bisa meningkatkan pendapatan masyarakat sehingga perekonomian masyarakatnya juga menjadi lebih baik. Sejak saat itulah para pemuda dan masyarakat Desa Timbanuh sangat gigih membangun desanya melalui sektor pariwisata. Dari adanya pengembangan wisata tersebut banyak peluang untuk membuat usaha sampingan seperti berdagang terutama ditempat wisata, menjadi porter bagi pendaki yang ingin mendaki gunung 
Rinjani dan jadi tukang parkir dan menyewa tempat penginapan. Hal ini tentu saja akanberpengaruh pada pendapatan masyarakat setempat.

\section{Perumusan Masalah}

1. Kegiatan atau usaha-usaha apa saja yang dapat memberi nilai tambah pada masyarakat Desa Timbanuh dari pengembangan pariwisata ?

2. Bagaimana dampak pengembangan pariwisata terhadap pendapatan masyarakat di Desa Timbanuh Kecamatan Pringgasela Kabupaten Lombok Timur?

\section{Tujuan Penelitian}

1. Untuk mengetahui kegiatan atau usaha-usaha yang memberi nilai tambah pada masyarakat Desa Timbanuh Kecamatan Pringgasela, Kabupaten Lombok Timur.

2. Untuk mengetahui dampak pengembangan pariwisata terhadap pendapatan masyarakat di Desa Timbanuh Kecamatan Pringgasela Kabupaten Lombok Timur.

\section{KAJIAN PUSTAKA}

\section{Konsep Pariwisata}

Kepariwisataan adalah segala sesuatu yang berhubungan dengan penyelenggaraan pariwisata (Yoeti, 1997, p.194). Wisata merupakan suatu kegiatan perjalanan atau sebagian dari kegiatan tersebut yang dilakukan secara sukarela serta bersifat sementara untuk menikmati obyek dan daya tarik wisata. Sedangkan wisatawan adalah orang yang melakukan kegiatan wisata. "Tourism is an integrated system and can be viewed in terms of demand and supply. The demand is made up of domestic and international tourist market. The supply is comprised of transportations, tourist attractions and activities, tourist facilities, services and related infrastructure, and information and promotion. Visitors are defined as tourist and the remainder as same-day visitors".

Pada garis besarnya, definisi tersebut menunjukkan bahwa kepariwisataan memiliki arti keterpaduan yang di satu sisi diperani oleh faktor permintaan dan faktor ketersediaan. Faktor permintaan terkait oleh permintaan pasar wisatawan domestik dan mancanegara. Sedangkan faktor ketersediaan dipengaruhi oleh transportasi, atraksi wisata dan aktifitasnya,fasilitas-fasilitas, pelayanan dan prasarana terkait serta informasi dan promosi. 
Menurut definisi yang luas pariwisata adalah perjalanan dari satu tempat ke tempat lain, bersifat sementara, dilakukan perorangan maupun kelompok, sebagai usaha mencari keseimbangan atau keserasian dan kebahagiaan dengan lingkungan hidup dalam dimensi sosial, budaya, alam dan ilmu.

Menurut Undang-Undang Nomor 10 Tahun 2009 tentang kepariwisataan, "pariwisata" adalah berbagai macam kegiatan wisata dan didukung fasilitas serta layanan yang disediakan masyarakat setempat, sesama wisatawan, pemerintah, pemerintah daerah dan pengusaha. (UU Nomor 10 Tahun 2009, dalam Kuncoro, 2014; 141).

Menutur WTO atau Word Tourism Organization (1998) dalam Kuncoro, 2019; 141, pariwisata adalah kegiatan manusia yang melakukan perjalanan ke dan tinggal di daerah tujuan di luar lingkungan kesehariannya, Perjalanan dianggap sebagai perjalanan wisata bila memenuhi tiga persyaratan yang diperlukan, yaitu:

a. Harus bersifat sementara

b. Harus bersifat sukarela (voluntary) dalam arti tidak terjadi karena dipaksa.
c. Tidak bekerja yang sifatnya menghasilkan upah ataupun bayaran.

Dalam kesimpulannya pariwisata adalah keseluruhan fenomena (gejala) dan hubungan-hubungan yang ditimbulkan oleh perjalanan dan persinggahan manusia di luar tempat tinggalnya. Dengan maksud bukan untuk tinggal menetap dan tidak berkaitan dengan pekerjaan-pekerjaan yang menghasilkan upah.

Suatu obyek pariwisata harus memenuhi tiga kriteria agar obyek tersebut diminati pengunjung, yaitu: a. Something to see, b. Something to do, dan c. Something to buy (Yoeti, 1985).

Dalam pengembangan pariwisata perlu ditingkatkan langkah-langkah yang terarah dan terpadu terutama mengenai pendidikan tenaga-tenaga kerja dan perencanaan pengembangan fisik. Kedua hal tersebut hendaknya saling terkait sehingga pengembangan tersebut menjadi realistis dan proporsional.

\section{Dampak Ekonomi Pariwisata}

Perkembangan suatu daerah tujuan wisata sangat dipengaruhi oleh keadaan ekonomi daerahnya, majunya perekonomian daerah tersebut dan 
berkembangnya berbagai sektor yang ada di daerah sekitarnya. Berkembangnya pariwisata menyebabkan pembangunan sarana dan prasarana pariwisata pun akan semakin berkembang, sehingga dapat meningkatan kenyamanan wisatawan. Demikian juga sebaliknya, pariwisata pun mampu mengangkat sektor-sektor ekonomi lainnya berkembang menjadi lebih baik. Kegiatan pariwisata akan menimbulkan permintaan (demand) akan barang dan jasa yang selanjutnya akan merangsang pertumbuhan produksi sehingga bertambahnya lapangan kerja yang dapat meningkatkan pendapatan masyarakat (Yoety, 2008).

Pada kondisi krisis ekonomi, sektor pariwisata diharapkan berperan sebagai penyelamat ekonomi, karena mampu menghasilkan pendapatan yang cukup tinggi. Pariwisata memiliki efek pengganda (multiplier effect) yang tinggi dibandingkan dengan sektor-sektor lainnya. Keberlanjutan kegiatan wisata di suatu daerah sangat dipengaruhi oleh kelangsungan hidup perekonomiannya. Oleh karena itu perlu adanya wawasan tentang pengelolaan sumberdaya yang menghasilkan manfaat ekonomi secara langsung bagi masyarakat sekitar (local community), yaitu pertumbuhan ekonomi yang dinikmati oleh masyarakat (Mulyaningrum, 2005).

Wisatawan yang datang berkunjung pada suatu negara atau DTW merupakan sumber pendapatan (income generation) dan sekaligus juga berfungsi sebagai alat pemerataan (redistribution of income) bagi penduduk suatu negara, sedikitnya bagi orang-orang dalam bisnis pariwisata di DTW yang dikunjungi (Yoeti, 2008:243). Menurut Clement (dalam Yoeti, 2008:248), setelah wisatawan datang pada suatu negara atau DTW, mereka pasti akan membelanjakan dollarnya pada perusahaan-perusahaan kelompok industri seperti: Accommodations, Food and Beverages, Purchases, Local Transportation, dan lain sebagainya untuk memenuhi kebutuhan (needs) dan keinginan (wants) selama mereka tinggal di daerah tersebut. Uang yang dibelanjakan oleh wisatawan itu, setelah dibelanjakan tidak berhenti beredar, akan tetapi berpindah dari satu tangan ke tangan orang lain atau dari satu perusahaan ke perusahaan lainnya. Ini akan menciptakan keterkaitan berbagai sektor terhadap sektor pariwisata. Satu hal yang perlu diketahui bahwa penglipatgandaan (multiplier effect) yang terjadi tidak sama, akan tetapi bervariasi dari suatu sektor ke sektor lainnya. 
Selain dampak ekonomi secara nasional, pada tingkatan daerah dan desa industri pariwisata mempengaruhi ekomomi daerah. Menurut Anna Spencele, Coroline Ashely dan Melissa De Kock (2009 dalam Wawanudin, 2013). kepariwisataan dapat secara potisif mempengaruhi pembangunan ekonomi daerah/desa melalui cara-cara sebagai berikut:

a. Stimulasi pembentukan pertumbuhan perusahaan;

b. Membawa pasar ekspor tepat untuk banyak sector;

c. Menstimulasi pembangunan infrastruktur baru dan layanan transportasi;

d. Bersama-sama meningkatkan keterampilan tenaga kerja;

e. Berkontribusi pada pajak di pemerintahan pusat, termasuk membayar biaya atau ijin kepada pemerintah daerah;

f. Menyediakan insentif dan dana untuk sumber daya alam, budaya dan sejarah yang harus ditangani dengan cara yang lebih berkesinambungan

\section{Pendapatan Masyarakat}

Pendapatan dari sektor pariwisita merupakan sumber dana bagi suatu daerah dimana pariwisata itu berada. Dengan semakin meningkatnya kunjungan wisata, berarti semakin bertambah pengeluaran wisatawan yang berdampak naiknya permintaan barang atau jasa-jasa yang diperlukan wisatawan. Dari proses tersebut berakibat pada bertambahnya lapangan kerja yang berarti menaikkan pendapatan masyarakat. Dengan meningkatnya pendapatan masyarakat setempat, berarti kesejahteraan masyarakat meningkat pula dan terdapat banyak alternatif jenis usaha sehingga meningkatkan motivasi masyarakat untuk bekerja yang diwujudkan dalam keterlibatan mereka pada pemanfaatan potensi pariwisata yang ada.

Dengan berkembangnya kegiatan pariwisata tersebut akan terdapat banyak alternatif jenis usaha yang ada. Hardinoto (1996) berpendapat bahwa pengembangan pariwisata bisa mengentaskan kemiskinan daerah. Hal ini dapat terjadi karena pariwisata menyangkut banyak bidang seperti pertanian, perikanan, peternakan, dan lain sebagainya yang dapat dihasilkan masyarakat di daerah tujuan wisata. Perbaikan pendapatan dapat seiring dengan perbaikan kesehatan, pendidikan, dan lain-lain.

\section{Penelitian Terdahulu}

Achadiat Dritasto dan Annisa Ayu Anggraeni (2013) dengan judul "Analisis Dampak Ekonomi Wisata Bahari Terhadap 
Pendapatan Masyarakat di Pulau Tidung".

Tujuan dari penelitian ini adalah menganalisis dampak ekonomi yang ditimbulkan oleh kegiatan wisata terhadap pendapatan masyarakat. Penelitian ini bersifat deskriptif kuantitatif dengan mengunakan metode analisis deskriptif. Hasil penelitian mengungkapkan bahwa Pulau Tidung yang merupakan salah satu pulau di Kabupaten Administrasi Kepulauan Seribu yang dalam perkembanganya dikelola langsung oleh masyarakat setempat dan dengan terkaitnya masyarakat dalam kegiatan wisata di Pulau Tidung, memberikan dampak ekonomi pada masyarakat, berupa pendapatan. Secara umum kegiatan wisata yang ada di Pulau Tidung telah memberikan dampak ekonomi kepada masyarakat walaupun dampak yang dirasakan terbilang cukup kecil.

Rusdin (2016); “Dampak Pengembangan Wisata Bahari Pantai Toronipa Terhadap Perekonomian Masyarakat di Kelurahan Toronipa Kecamatan Soropia Kabupaten Konawe". Tujuan penelitian ini adalah untuk mengetahui dampak pengembangan wisata bahari pantai
Toronipa terhadap perekonomian masyarakat di Kelurahan Toronipa Kecamatan Soropia Kabupaten Konawe. Metode pengumpulan data dimulai dari observasi penelitian dan wawancara langsung pada sasaran penelitian dan dokumentasi. Hasil penelitian diperoleh bahwa sebelum pengembangan obyek wisata aktivitas ekonomi masyarakat pada umumnyasebagai petani dan nelayan, namun sesudah pengembangan obyek wisata melalui penyediaan sarana dan prasarana kemudian hubungan antara masyarakat dengan wisatawan yang akrab sehingga meningkatkan jumlah pengunjung, aktivitas ekonomi masyarakat bertambah yakni sebagai pedagang (kios/kantin) dan penyedia fasilitas seperti banana boat, ban pelampung, gazebo, ruang bilas dan penginapan, meningkatkan pendapatan masyarakat secara signifikan. Dengan demikian pengembangan obyek wisata memberikan dampak yang positif bagi peningkatan perekonomian masyarakat di Kelurahan Toronipa. 


\section{Kerangka Pemikiran}

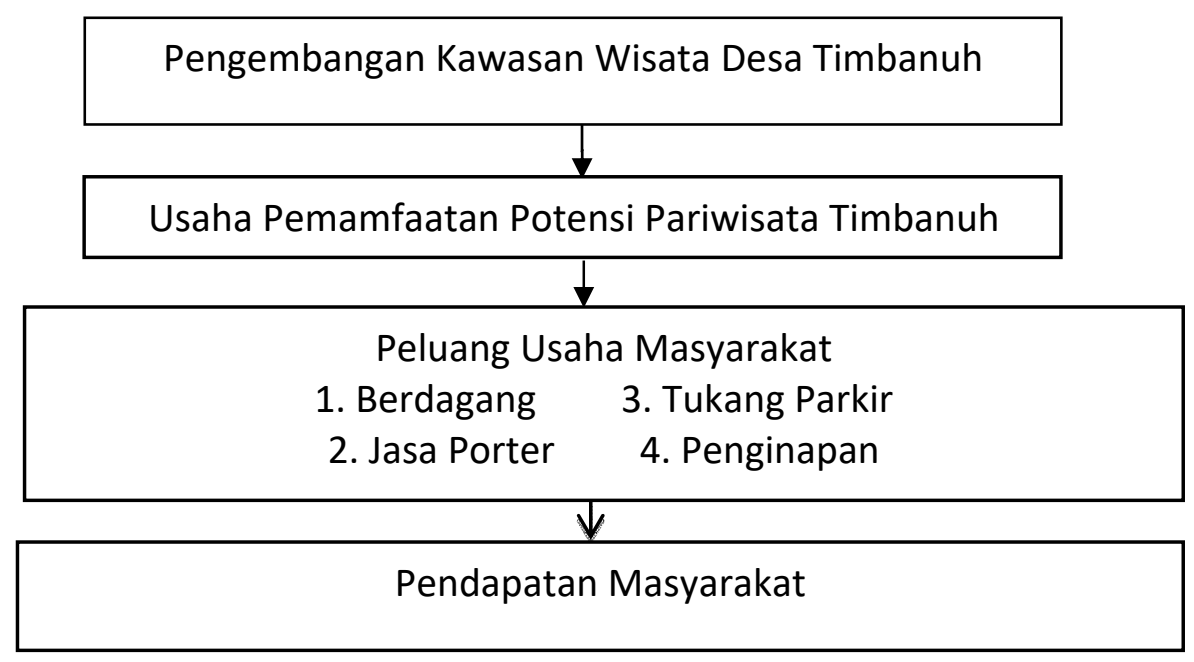

\section{METODE PENELITIAN}

\section{Jenis Penelitian}

Jenis penelitian yang digunakan dalam penelitian ini adalah penelitian deskriptif. Prosedur pemecahan masalah pada metode ini adalah dengan cara mengambarkan objek penelitian pada saat keadaan sekarang berdasarkan fakta-fakta sebagaimana adanya, kemudian dianalisis dan di interprestasikan, bentuknya berupa survey dan studi perkembangan. (Sofian, Siregar 2013:8).

\section{Lokasi Penelitian}

Penelitian ini dilaksanakan di Desa Timbanuh Kecamatan Pringgasela, Kabupaten Lombok Timur. Lokasi tersebut diambil sebagai lokasi penelitian dengan pertimbangkan bahwa: 1). Daerah tersebut merupakan daerah tujuan wisata yang sedang melakukan pengembangan di bidang pariwisata. 2). Salah satu jalur pendakian (jalur selatan) menuju ke Gunung Rinjani.

\section{Metode Pengumpulan Data}

Metode pengumpulan data dalam penelitian ini dilakukan dengan sampel survey.

\section{Populasi dan Sampel Penelitian}

Populasi dalampenelitian ini adalah masyarakat Desa Timbanuh yang memiliki peluangusaha atau yang terlibat langsung disektor pariwisata seperti pedagang disekitar kawasan pariwisata, porter, pemandu wisata (pramu wisata), tukang parkir dan pemilik penginapan (homestay). Adapun jumlah populasi masyarakat yang memiliki peluang usaha atau yang terlibat langsung dalam sector pariwisata dalam penelitian ini sebanyak 250 kepala keluarga. 
Sampel dalam penelitian ini ditentukan dengan menggunakan rumus Slovin (Nazir.2011).

$$
\mathrm{n}=\frac{N}{1+N_{\sigma^{2}}}
$$

Dimana:

$\mathrm{n}=$ Ukuran Sampel

$\mathrm{N}=$ Ukuran Populasi

$\mathrm{E}=$ Kelonggaran ketidaktelitian karena kesalahan pengambilan Sampel yang ditolerir, dalam penelitian ini menggunakan $10 \%$.

Maka, $\mathrm{n}=\frac{2 \mathrm{E0}}{1+(260)(0,1)^{2}}=\frac{260}{8,6}=71,428$, dibulatkan menjadi 71 responden.

Masing-masing adalah: Pedagang sebanyak 26 orang, Jasa Porter sebanyak 39 orang, Tukang Parkir sebanyak 5 orang dan pemilik penginapan sebanyak 1 orang.

\section{Teknik dan Alat Pengumpulan Data}

Teknik pengumpulan data dalam penelitan ini adalah dengan wawancara, observasi dan dokumentasi. Sementara alat Pengumpulan data dalam penelitian ini yaitu kuisioner

\section{Jenis dan Sumber Data}

Jenis data pada penelitian ini adalah data kuantitatif dan data kualitatif. Sementara sumber data adalah data primer dan data sekunder.

\section{Variabel Penelitian}

Untuk melihat pengembangan pariwisata di Desa Timbanuh, indikatornya adalah perubahan-perubahan yang dilakukan terkait dengan adanya kebijakan pengembangan pariwisata di Kabupaten Lombok Timur, seperti adanya perbaikan/pengaspalan jalan menuju desa Timbanuh, pembukaan jalan baru menuju tempat-tempat wisata Desa Timbanuh, adanya fasilitas penunjang seperti disedikannya toilet umum, tempat sampah, dan adanya street sign menuju lokasi wisata serta tempat beristirahat sepanjang jalur taking menuju gunung rinjani. Sementra variabel lainnya adalah Pendapatan dan Kegiatan masyarakat.

Pendapatan adalah besarnya penghasilan rata-rata perbulan yang diperoleh oleh kepala keluarga atau masyarakat Desa Timbanuh dalam ukuran ( $\mathrm{Rp}$ ) dari adanya pengembangan wisata alam sesudah dan sebelum adanya pengembangan. Dimana Pendapatan yang dimaksud adalah:
a. Pendapatan dari berdagang;
b. Pendapatan dari pekerjaannya sebagai jasa porter;
c. Pendapatan sebagai tukang parkir;
d. Pendapatan penyewa penginapan. 
Kegiatan masyarakat yang dimaksud dalam penelitian ini adalah:
a. Pedagang;
b. Jasa porter;
c. Tukang parkir;
d. Menyewakan Penginapan.

\section{Prosedur Analisis Data}

Untuk melihat dampak pengembangan wisata alam terhadap peningkatan perekonomian masyarakat digunakan analisis pendapatan yang dapat memberi nilai tambah pada masyarakat digunakan rumus sebagai berikut:

\section{$N R=T R-T C, T R=Q \times P, T C=T V C+T F C$}

Dimana:

NR = Pendapatan bersih yang diterima (Pedagang, jasa porter, tukang parkir, penyewa penginapan)

$\mathrm{TR}=$ Pendapatan kotor yang diterima (Pedagang, jasa porter, tukang parkir, penyewa penginapan)

$\mathrm{TC}=$ Seluruh biaya yang dikeluarkan (Pedagang, jasa porter, tukang parkir, penyewa penginapan)

$\mathrm{Q}=$ Jumlah barang yang dikeluarkan atau yang dihasilkan

$\mathrm{P}=$ Harga

TVC $=$ Total variable cost (biaya variabel)

TFC $=$ Total Fixed Cost (biaya tetap).
Kemudian untuk mengetahui apakah ada perbedaan pendapatan antara sebelum adanya pengembangan pariwisata dan sesudah adanya pengembanganpariwisata di Desa Timbanuh di gunakan alat analisis uji Independent Sample T-test.Uji statistik ini adalah uji yang menyatakan bahwa tidak ada hubungan antara dua sampel. Tujuan dari Uji Independent Sample T-test untuk mengetahui perbedaan antara pendapatan masyarakat yang berada di Desa Timbanuh sebelum adanya pengembangan wisata alam dan sesudah adanya pengembangan wisata alam.

\section{HASIL DAN PEMBAHASAN}

Mata pencaharian penduduk di Desa Timbanuh berbeda-beda, ada yang bekerja sebagai petani, beternak, berkebun, berdagang, pertambangan, jasa, kehutanan. Berdasarkan hasil penelitian, penduduk yang bekerja dapat dilihat pada Tabel 1 berikut: 
Tabel 2. Jumlah Penduduk Desa Timbanuh yang Bekerja Berdasarkan Jenis Mata Pencaharian

\begin{tabular}{|l|l|l|l|}
\hline No & \multirow{2}{*}{ Jenis Mata Pencaharian } & \multicolumn{1}{|c|}{ Jumlah (Jiwa) } & \multicolumn{1}{c|}{ Persentase (\%) } \\
\hline 1 & Beternak & 221 & 21,37 \\
\hline 2 & Berkebun & 475 & 45,93 \\
\hline 3 & Pertambangan & 50 & 4.83 \\
\hline 4 & Kehutanan & 125 & 12,08 \\
\hline 5 & Jasa & 72 & 6,96 \\
\hline 6 & berdagang & 66 & 6,38 \\
\hline 7 & Petani & 25 & 2,41 \\
\hline Jumlah & 1,034 & 100 \\
\hline
\end{tabular}

Sumber: Kantor Desa Timbanuh 2017

Tabel 1 menunjukkan kelompok penduduk berdasarkan jenis mata pencharian yang bekerja pada berbagai bidang pekerjaan berjumlah 1,043 orang. Penduduk dengan jenis mata pencharian terbanyak yaitu berkebun dengan jumlah 475 orang atau 45,93 persen. Sedangkan jenis mata pencharian paling sedikit yaitu pekerja sebagai petani 25 orang atau 2,41 persen.

\section{Pengembangan Pariwisata di Desa Timbanuh}

Pembangunan paiwisata di Desa

Timbanuh lebih banyak difokuskan pada obyek wisata alam. Jenis wisata yang ditawarkan diantaranya: Pertama, wisata Trecking Gunung Rinjani, dimana Desa Timbanuh merupakan salah satu jalur pendakian untuk jalur selatan menuju Gunung Rinjani yang sudah resmi di Kabupaten Lombok Timur. Jalur pendakian ini juga menawarkan pemandangan yang berbeda dari jalur

yang lainnya yaitu berupa kawasan hutan dan edelwis. Ini yang menjadi salah satu daya tarik jalur pendakian dari Timbanuh yang menyajikan jalur Trecking yang sejuk karna melewati hutan lebat dan padang savanna yang kini mulai jarang dikawasan Gunung Rinjani. Kedua adalah wisata air terjun, Desa Timbanuh merupakan salah satu kawasan yang berada dikawasan Kaki Gunung Rinjani yang memiliki banyak air terjun dengan jumlah air terjun 17 macam. Namun yang resmi dikelola Pemerintah Desa Timbanuh hanya 3 air terjun yaitu air terjun semporonan, air terjun mayong polak, dan air terjun reban bongkot. Sisanya terkendala karna jalur yang ekstrim dan sulit dijangkau. Ketiga, tempat pemandian, dimana Desa Timbanuh memiliki tempat pemandian 
diataranya kolam pesanggrahan, prosotan alami air sleong dan pemandian reban bongkot. Keempat situs yang bersejarah, Desa Timbanuh pernah dijadikan basis pertahanan dan markas kolonial belanda yaitu sebuah bangunan rumah yang dijadikan tempat peristirahatan dan tempat tinggal kolonial Belanda bangunanya tetap utuh hingga sekarang.

Dari potensi wisata alam yang telah disebutkan, diketahui banhwa Desa Timbanuh memiliki banyak potensi wisata yang harus dikembangkan agar bermanfaat baik bagi masyarakat setempat maupun masyarakat luar Desa Timbanuh. Tujuan dari program Dinas Pariwisata adalah untuk menyediakan kawasan wisata yang mudah dijangkau oleh wisatawan baik domestic maupun mancanegara. Sehingga Pembangunan wisata di Desa Timbanuh terus dikembangkan diantaranya pembangunan jalan menuju lokasi Desa Timbanuh dengan melakukan pengaspalan jalan. Pengaspalan dilakukan dari masuknya kawasan Desa Timbanuh sampai ujung jalan desa Timbanuh. Selain itu, beberapa jalan baru sudah banyak dibuka untuk menunjang dan mempermudah akses jalanya prekonomian masyarakat setempat, dan menyediakan fasilitas- fasilitas umum seperti tempat ibadah, tempat menginap, toilet, dan tempat sampah yang kini sudah ada dimasingmasing tempat wisata di Desa Timbanuh. Selain itu sudah disediakan pusat informasi seputaran kawasan wisata Timbanuh yang kini kantornya untuk sementara berada di Kantor Desa Timbanuh. Sejak dibangunya sarana prasarana dan fasilitas di Desa Timbanuh parawisatawan mancanegara maupun domestic sudah mulai banyak yang berkunjung di Desa Timbanuh.

\section{Aktivitas Ekonomi Masyarakatdan Pendapatan Di Desa Timbanuh Sebelum Adanya Pengembangan Pariwisata}

Sumber penghidupan masyarakat di Desa Timbanuh sebelum pengembangan obyek wisata pada umumnya adalah pada sector pertanian, seperti perkebunan, peternakan, dan pertanian dengan jumlah pendapatan yang rata-rata masih tidak terlalu besar. Seperti terlihat pada Tabel 2.

Dari data pada table 2 dapat dilihat bahwa pendapatan masyarakat perbulannya masih tergolong kecil dengan rata-rata pendapatan sebesar $\mathrm{Rp}$ 1.897.892,80,-. Terutama dari kegiatan berdagang, masyarakat hanya memperoleh rata-rata pendapatan sebesar Rp 622.157,- Pendapatan 
masyarakat tergolong minim untuk memenuhi kebutuhan keluarga yang rata- rata terdiri dari 4 sampai 5 anggota keluarga.

Tabel 3. Prosentase Jumlah Responden berdasarkan aktivitas dan Rata-Rata Pendapatan perbulan Sebelum Pengembangan Pariwisata

\begin{tabular}{|l|l|l|lc|}
\hline No & Jenis Aktivitas & Prosentase Jumlah Responden (\%) & \multicolumn{2}{|l|}{ Rata-rata Pendapatan (Rp) } \\
\hline 1 & Berdagang & 5,63 & $\mathrm{Rp}$ & $622,157.00$ \\
\hline 2 & Beternak & 28,16 & $\mathrm{Rp}$ & $4,779,563.00$ \\
\hline 3 & Berkebun & 26,76 & $\mathrm{Rp}$ & $2,376,516.00$ \\
\hline 4 & Betani & 28,16 & $\mathrm{Rp}$ & $1,711,228.00$ \\
\hline 5 & IRT & 11,26 & $\mathrm{Rp}$ & - \\
\hline \multicolumn{2}{|l|}{ Rata-Rata Pendapatan } & $\mathrm{Rp}$ & $\mathbf{1 , 8 9 7 , 8 9 2 . 8 0}$ \\
\hline
\end{tabular}

Sumber: Data Primer diolah

untuk menambah penghasilan

Aktivitas Ekonomi Responden dan pendapatan setelah pengembangan Pariwisata

Adanya kegiatan kepariwisataan membuka lapangan kerja dan lapangan usahabaru bagi warga desa Timbanuh, baik langsung maupun tidak langsung. Dengan adanya perbaikan prasarana jalan warga masyarakat lebih memiliki peluang untuk melakukan berbagai kegiatan ekonomi seperti berdagang ataupun memperlancar pengangkutan barang hasil perkebunan taupun pertanian menuju tempat pemasaran. Dengan pembangunan penginapan ditempat wisata ini berarti memberi peluang kepada masyarakat untuk dapat menghasilkan uang dari usaha tersebut. Banyaknya wisatawan yang berkunjung ke Desa Timbanuh, khusunya disekitar tempat wisata dapat memberikan peluang masayarakat dari berbagai kegiatan yang ditawarkan untuk memenuhi kebutuhan wisatawan. Sesudah adanya pengembangan obyek wisata di Desa Timbanuh masyarakat yang tadinya bekerja berkebun, beternak ataupun bertani, mempunyai kerja sampingan ataupun beralih profesi tidak tetap kesector pariwisata seperti berdagang, penyedia jasa layanan porter, tukang parkir dan menyewa penginapan.

Adanya tambahan sumber mata pencaharian dari sector pariwisata setelah adanya pengembangan berbagai obyek wisata, menyebabkan desa ini ramai dikunjungi oleh para wisatawan, baik local, regional maupun mancanegara. Bertambah ramainya kunjungan wisatawan dapat meningkatkan pendapatan masyarakat. 
Berdasarkan hasil penelitian, diperoleh beberapa jenis kegiatan/pekerjaan yang dapat ditekuni oleh masyarakat setelah adanya pengembangan pariwisata di desa Timbanuh yang memberikan nilai tembah tersediri bagi masyarakat, yakni berupa tambahan pendapatan yang lebih besar

Tabel 4. Prosentase Jumlah Responden Berdasarkan Aktivitas dan Rata-rata Pendapatan Perbulan Sesudah Pengembangan Pariwisata

\begin{tabular}{|l|l|l|l|}
\hline NO & \multicolumn{1}{|c|}{$\begin{array}{c}\text { Jenis Aktivitas } \\
\text { Ekonomi }\end{array}$} & \multicolumn{1}{|c|}{$\begin{array}{c}\text { Prosentase Jumlah } \\
\text { Responden (\%) }\end{array}$} & Rata-rata pendapatan (Rp) \\
\hline 1 & Berdagang & 36,61 & $1,768,037.00$ \\
\hline 2 & Jasaporter & 54,92 & $1,201,564.00$ \\
\hline 3 & Tukangparkir & 7,04 & $755,000.00$ \\
\hline 4 & Penginapan & 1,40 & $2,629,261.00$ \\
\hline 5 & Berkebun & 14,08 & $3,197,183.00$ \\
\hline 6 & Beternak & 11,26 & $3,808,383.00$ \\
\hline 7 & Bertani & 7,04 & $\mathbf{2 , 1 2 9 , 8 3 3 . 0 0}$ \\
\hline Rata-rata pendapatan & & $\mathbf{2 1 2 , 7 5 1 . 5 7}$ \\
\hline
\end{tabular}

Sumber:Data Primer diolah 2018

Pada tabel 3 terlihat bahwa jenis aktivitas ekonomi sesudah adanya pengembangan obyek wisata alam di Desa Timbanuh bertambah. Selain sebgai pekebun, peternak, pedagang dan petani, ada tambahan jenis pekerjaan lagi, yakni sebagai porter, tukang parkir dan membuka jasa penginapan. Demikian pula halnya dengan pendapatan. Setelah adanya pembenahan terhadap obyek wisata alam yang ada di desa Timbanuh, dibandingkan dengan sebelum adanya pengembangan wisata. Untuk lebih jelasnya aktivitas ekonomi yang dilakukan oleh responden dan besarnya penghasilan perbulan yang diperoleh dapat dilihat pada Tabel berikut: 
sekitar kawasan wisata, bertambah, yang semula rata-rata pendapatan pedagang hanya $\mathrm{Rp} 622,157$,- bertambah menjadi Rp 1.768,037,- perbulan. Begitu pula halnya dengan masyarakat yang bekerja di perkebunanan dan pertanian, pendapatan mereka perbulannya mengalami peningkatan. Sementara hanya pendapatan penduduk yang beternak mengalami penurunan. Hal ini disebabkan karena ada beberapa penduduk yang beternak juga menggeluti pekerjaan baru sebagai porter. Pekerjaan sebagai porter juga memberikan pendapatan yang cukup besar yakni, rata-rata $\mathrm{Rp} 1,201,564,-$ perbulan. Pekerjaan sebagai porter sementara ini dijadikan sebagai propesi sampingan, selain propesi pokok mereka yakni petani, berkebun dan berternak. Selain sebagai pedagang dan penyedia layanan jasa porter masyarakat disekitar kawasan Timbanuh ada juga yang berpropesi sebagai tukang parkir dan penyedian penginapan (homestay) dengan rata-rata pedapatan untuk masyarakat yang berpropesi sebagai tukang parkir Rp 755,000,-. Penyedia layanan penginapan (homestay) dengan rata-rata pendapatan $\mathrm{Rp} 2,629,261,-$

Dampak Pengembangan Wisata Alam Terhadap Pendapatan Masyarakat
Adanya pengembangan wisata alam di Desa Timbanuh mempunyai dampak terhadap pendapatan/perekonomian masyarakat, terlihat dari aktivitas ekonomi masyarakat yang semakin beragam. Sebelum pengembangan pariwisata di Desa Timbanuh, aktivitas responden sebagian besar adalah berkebun, beternak, bertani dan hanya beberapa pedagang, dan setelah adanya pengembangan obyek wisata alam responden mendapatkan pekerjaan tambahan yang dapat memberi nilai tambah untuk menambah pendapatan.

Terjadinya peningkatan jumlah kunjungan wisatawan ke Desa Timbanuh setelah dilakukannya bebagai pembenahan terhadap obyek wisata alam yang ada di desa tersebut. Meningkatnya jumlah kunjungan ini berdampak pada bertambahnya ragam jumlah aktivitas yang dapat dilakukan oleh masyarakat sekitar untuk memenuhi kebutuhan wisatawan. Dengan adanya tambahan jenis aktivitas ekonomi masyarakat ini memberikan peluang pada peningkatan pendapatan masyarakat seperti yang terlihat pada hasil penelitian yang telah dipaparkan sebelumnya.

\section{Hasil Uji Independent Sample T-Test.}

Model analisis statistik yang digunakan adalah uji Independent Sample T-test.Uji 
statistik ini adalah uji yang menyatakan bahwa tidak ada hubungan antara dua sampel. Tujuan dari Uji Independent Sample T-test adalah untuk mengetahui apakah ada perbedaan rata-rata dari kelompok yang satu dengan kelompok lainnya.

Dari hasil uji independent Sampel T-Test diperoleh bahwa baik untuk pekerjaan responden sebagai pedagang, petani, pekebun, peternak menunjukkan hipotesis $\mathrm{H}_{0}$ ditolak sedangkan hipotesis $\mathrm{Ha}$ diterima. Artinya bahwa ada perbedaan pendapatan pedagang, petani, pekebun, maupun peternak sebelum adanya pengembangan wisata alam dan sesudah adanya pengembangan wisata alam di desa Timbanuh.

\section{KESIMPULAN DAN SARAN}

\section{Kesimpulan}

1. Pengembangan pariwisata memberikan dampak positif pada masyarakat desa Timbanuh. Sebelum pengembangan wisata alam Desa Timbanuh sebagian besar masyarakat bekerja berkebun dan beternak, namun sesudah pengembangan, masyarakat di Desa Timbanuh memiliki kegiatan/usahausaha yang lebih variatif dan memberi nilai tambah seperti menjadi pedagang, jasa porter, tukang parkir dan jasa penginapan.

2. Pengembangan pariwisata di Desa Timbanuh memberikan dampak berupa peningkatan pendapatan masyarakat, terlihat dari tingkat pendapatan sebelum dan sesudah adanya pengembangan, dimana rata-rata pendapatan masyarakat sebelum pengembangan pariwisata yaitu sebesar Rp 1,897,892,-/bulan dan sesudah ada pengembangan pariwisata rata-rata pendapatan sebesar Rp 2,212,751,-/bulan.

\section{Saran}

1. Dinas Pariwisata hendaknya memprakarsai terbentuknya Kelompok Sadar Wisata (POKDARWIS) di desa Timbanuh yang nantinya dapat berperan aktif sebagai penggerak dalam mendukung terciptanya iklim kondusif bagi tumbuh dan berkembangnya kepariwisataan di desa Timbanuh.

2. Masyarakat setempat diharapkan lebih aktif melakukan inovasiinovasi dan membuat berbagai aktivitas yang menarik wisatawan untuk lebih banyak berkunjung ke desa Timbanuh serta membuat berbagai kegiatan yang mendukung 
kepariwisataan yang terkait dengan masyarakat desa Timbanuh.

pembukaan peluang kerja bagi

\section{DAFTAR PUSTAKA}

Anonim. 2016. Lombok Timur Dalam Angka 2016. BPS Lombok Timur

--------, 2018, Balai Taman Nasional Gunung Rinjani

---------, 2018, Potensi Desa Timbanuh

--------, 2016. Metode Penelitian Kuantitatif dan R\&D. Penerbit: Alfabeta, Bandung.

Achadiat Anggraeni, 2013 Analisis Dampak Ekonomi Wisata Bahari Terhadap Pendapatan Masyarakat di Pulau Tidung

Kuncoro. Mudrajat, 2014, Ekonomika Regional, Teori dan Praktek, Rajawali Press, PT Raja Grafindo Persada Depok.

Rusdin. 2016. Dampak Pengembangan Wisata Bahari Pantai Toronipa Terhadap Perekonomian Masyarakat di Kelurahan Toronipa Kecamatan Soropia Kabupaten Konawe.Skripsi: Universitas Halu Oleo Kendari

Siregar, syofian. 2013. Metode Penelitian Kuantitatif. Jakarta: Prenada Media Group.

Todaro, M. 2000. Perkembangan Ekonomi, Edisi Kelima, Jakarta: Bumi Aksara. UndangUndang No. 9 Tahun 1990 Tentang Kepariwisataan.(n.d.)

Wahab, S. 1985. Manajemen Pariwisata, Jakarta: PT. Pradaya Paramita.

Wulandari, 2014, Dampak Kegiatan Pariwisata Di Pantai Indrayanti Terhadap Perekonomian Masyarakat Sekitar

Yoeti, O. A. 1985. Pariwisata Masalah dan Solusinya.Jakarta: PT. Pradya Paramita.

Yoeti, O. A. 1997. Pengantar Ilmu Pariwisata. Bandung: Angkasa

Yoeti, O. A. 2008. Ekonomi Pariwisata, Industri, Informasi dan Implementasi. Jakarta: Kompas 